\title{
Analysis on the Research Hotspots and Trends of Subject Service in University Libraries in China
}

\author{
Yuchen $\mathrm{Chi}^{1}$ Lixin Zhang ${ }^{2, *}$ Feng $\mathrm{Xu}^{3}$ \\ ${ }^{1}$ Northeast Normal University Library, Changchun, Jilin 130024, China \\ ${ }^{2}$ Changchun University of Technology Library, Changchun, Jilin 130000, China \\ ${ }^{3}$ Northeast Normal University Library, Changchun, Jilin 130024, China \\ *Corresponding author.Email: 105506909@qq.com
}

\begin{abstract}
Purpose/significance: As an important part of University Library service, subject service has become an indispensable service ability of University library. The improvement of subject service ability marks the direction of transformation and development of University Library in the future. Method/process: By means of scientific metrology, this paper makes statistics on the scientific literature in the field of subject service of University Libraries in China by using the visualization analysis tools Citespace and VOSviewer of knowledge atlas, and through the fitting degree analysis of price equation, understands the annual distribution of the amount of publications in this field and the trend of literature growth, and from (the distribution of the cooperation network between authors and institutions) and (Keywords co-occurrence analysis) and (cluster analysis) reveal the distribution of research power, research hotspots and evolutionary development context in this field. Results/conclusion: By sorting out the research literature in this field, we have fully grasped the current situation, hotspots and evolutionary trends of the subject service research in University Libraries in China, with help and benefit to contributing to the future research work.
\end{abstract}

\section{Keywords: University Library, subject service, research hotspots, price curve, situation analysis}

\section{INTRODUCTION}

In China, subject service reflects the core value and development prospect of university libraries, and also its nature of information services with wide horizons, academic orientation and customization [1]. It embodies the improvement of service capabilities and the ability of documents supply of university libraries [2]. The Tsinghua University Library first introduced and implemented the subject librarian system in China in 1998, which marked the beginning of the subject service practice of university libraries in China [3]. In the past 20 years, the subject service of university libraries in China has made great progress, and it has become an inevitable trend for libraries to develop in the aspects of knowledge, personalization, intelligence, and specialization. It is a new service model that takes subject librarians as the main body and professional subjects as the service object. It can meet the needs of users at different levels by establishing a resource platform classified by subjects and providing convenient one-stop services based on the subject [4]. In recent years, subject service has become one of the most important services promoted by many university libraries. By sorting out the subject service research of university libraries in China, the author learns about the current status, research hotspots, and trends of subject service research in university libraries in China, evaluates the core research results, predicts future development, and hopes that it can provide reference to both research and practice in the field of subject service of university libraries in China.

\section{DATA SOURCES AND RESEARCH METHODS}

\section{A. Data sources}

This article takes CNKI (China National Knowledge Infrastructure) Academic Journals Full-text Database (online) as the data sources. In order to ensure the recall rate of literature search, the advanced search is set as follows: Subject = "University Library" and "Subject Services", Literature Source = "All Journals", Publication Date from unlimited to December 31, 2018, and the search time was March 27, 2019. As a result, a total of 1685 articles were presented. After excluding irrelevant and less relevant articles such as in Proceedings and Newspapers, a total of 1,672 articles were selected as data sources for data processing and analysis. 


\section{B. Research methods}

Bibliometric analysis method, cluster analysis method, knowledge map visualization analysis method are adopted in this research and statistical tools such as Excel are also used to statistics and analyze the the publication data of subject service research in Chinese university libraries, the distribution of annual publications, the growth trend of literature, and the distribution of researchers. Meanwhile, the visual software CiteSpaceV and VOSviewer are used to draw knowledge maps of authors and institutions' cooperation networks, research hotspots and trends to reveal knowledge structure and characteristics of the literature, and then to conduct a comprehensive analysis of the research situation of subject service in Chinese university libraries.

\section{RESULTS ANALYSIS}

\section{A. Analysis of distribution of annual articles and literature growth trend}

The searching result shows that the first person who proposed the concept of "subject librarian" in China was Chen Jing, a scholar of Fuzhou University. In his article titled "Establishing a Professional Team of 'Subject Librarian '" which published in "Jiangxi Library Journal"( now renamed "Library Research") in 1987, he divided the librarians into two categories - "subject librarian" and "assistant librarian", and explained the concept of "subject librarian" and their specific working content [5]. This is considered to be the beginning of the subject service research of Chinese university libraries. "Fig. 1" shows the annual articles of the subject service research of university libraries in China from which we can see that the research on it can be roughly divided into the following three stages. The first stage is the elementary period(1997-2006). Due to the limitations of China's technical conditions at that time, subject services were carried out very slowly or even stagnated at this stage. In the second stage (20072011) it has developed due to the continuous advancement of computer technology and Internet technology, which has increased the number of channels for document acquisition, as well as the amount of digital documents, but still at a low and unstable pace. The third stage is a rapid development period (2012 to present). The emergence of some emerging technologies such as mobile Internet, big data, and cloud computing has resulted in an explosion of digital resources, which has greatly improved the capabilities of subject service in university libraries. It can also be seen from the amount of literature that the amount of literature in 2012 increased nearly double compared to 2011, and has been increasing year after year, with a significant increase. This shows that the research on the subject service of university libraries in China is in a period of rapid development.

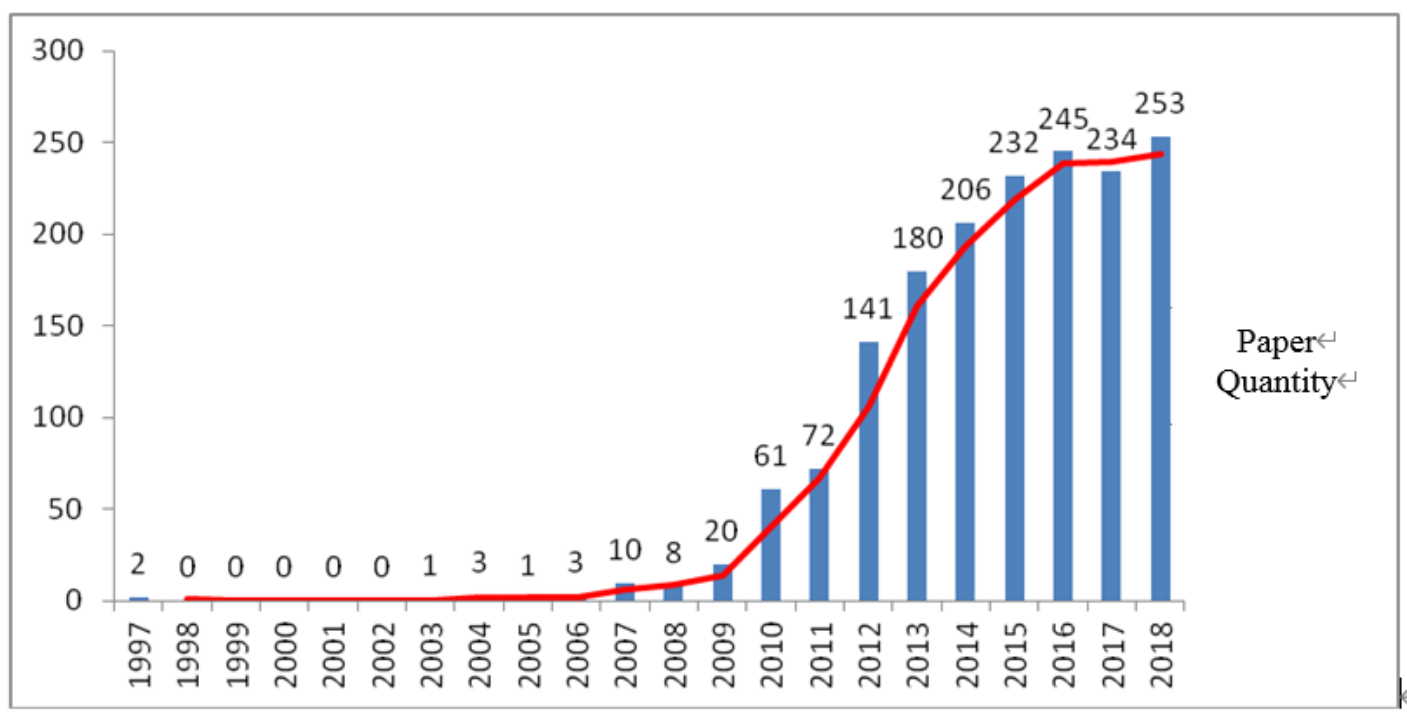

Fig. 1. Distribution of annual articles about subject service research of university libraries in China.

The exponential growth model of the number of literature proposed by American intelligence science expert D.J. Price can better predict the trend of literature growth and further reveal the law of the number of literature over time [6] based on which the author draws a comparison and analysis chart of fitting degree of the Price Curve and the cumulative amount of published articles of the subject service research of Chinese university libraries ("Fig. 2"). It can be seen from "Fig. 2" that the research on the subject service of university libraries in China has been developing well, and the amount of literature output has been increasing year by year. By simulating the growth trend of the subject service literature accumulation in China's 
university libraries, it is obtained that the Price fitting curve conforms to an exponential function ( $\mathrm{Y}=$ $2 \mathrm{e} 0.358 \mathrm{x})$, and the degree of curve fitting is very high $(\mathrm{R} 2=0.996)$ that shows that the cumulative growth of the literature on the subject service research of university libraries in China is in full compliance with the growth index of the Price Index and also further indicates that the subject service of college libraries in China is currently in a period of rapid development. It also proves that the searching strategy adopted in this research is correct and the results are scientific.

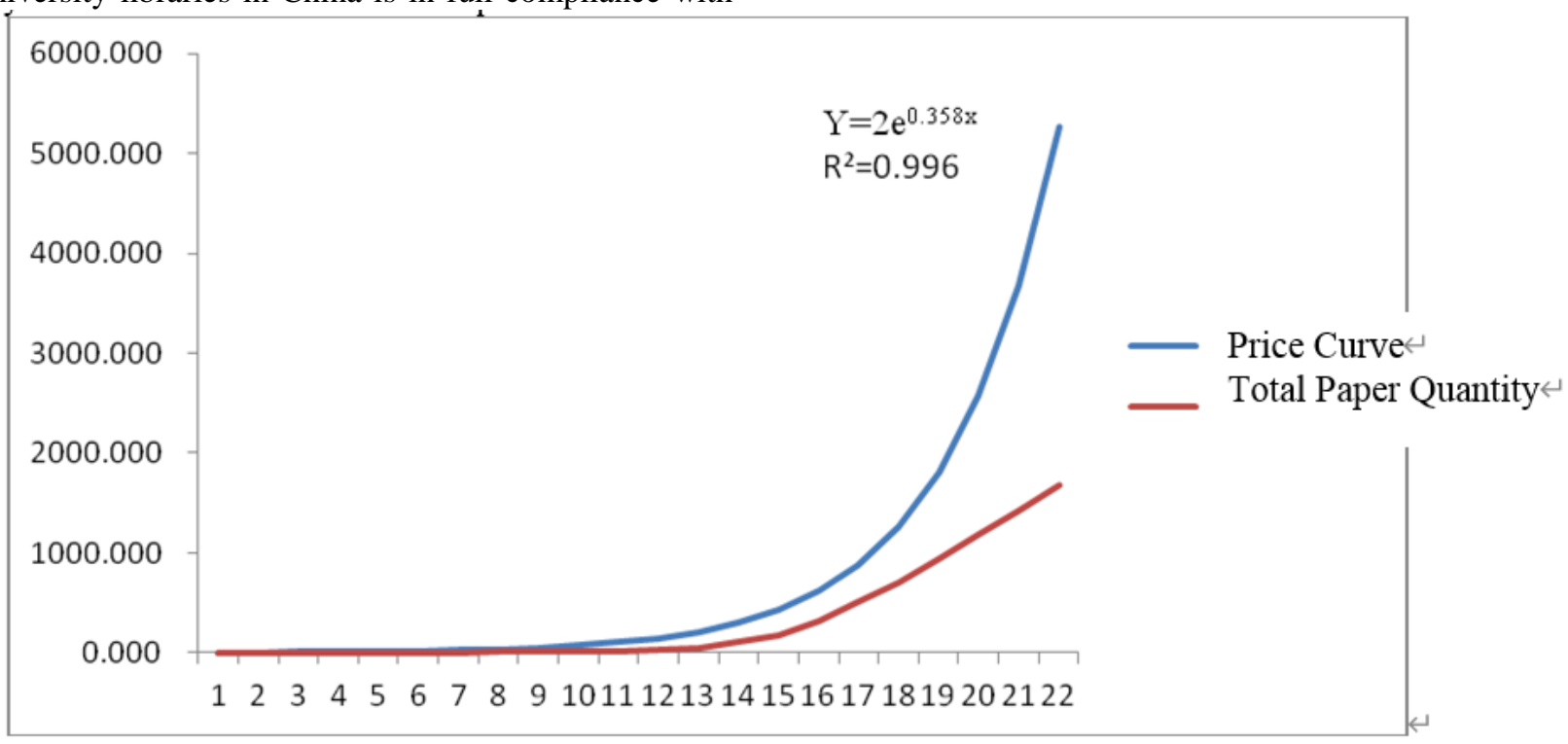

Fig. 2. Comparison and analysis of the cumulative amount of published articles and the fitting degree.

\section{B. Analysis of researchers and institutions}

1) Distribution of authors' cooperation network: The distribution of authors' cooperation network can reflect the distribution and cooperation of the researchers engaged in subject service research in Chinese university libraries. By exporting the data in Refworks format and importing it into VOSviews software, we obtained distribution maps of authors' cooperation network in Density Visualization and Overlay Visualization. As shown, there are 2,037 authors, 85 link points, and a total chain length of 106 in the authors' cooperation network of subject service research in Chinese university libraries. That means the authors' cooperation network of subject service research in Chinese university libraries is relatively loose, and most of them are the results of independent research. The following seven researcher cooperation groups with strong cohesion have been formed ("Table I") while other cooperation groups would not be discussed in detail in this paper due to reasons such as less articles, loose cooperation, or fewer scholars. There are 36 core authors in the 7 main authors' cooperation groups, which are respectively distributed in 7 clusters with different colors that range from dark to light, indicating the amount of authors' articles published from large to small. The dark authors (Ma Fangzhe and
Li Feng in Cluster 1, Song Haiyan and Lan Xiaoyuan in Cluster 2, Pan Wei and Huang Min in Cluster 3, Guo Jing in Cluster 4, Yang Mei in Cluster 5, Huang Qinling in Cluster 6 and $\mathrm{Li} \mathrm{Li}$ in Cluster 7) with large quantity of articles are the core authors in each cluster. Among them, Cluster 1 with 9 authors as formed the most important core research group in the subject service research of university libraries in China, and Cluster 7 with only 2 authors has the least number. Throughout the entire cooperation network, Guo Jing is at the core of the outward diffusion trend. It means that Guo Jing who has published most articles in this field is the core research strength of the subject service research of Chinese university libraries. The core authors and highyielding authors in this field mainly appeared after 2012 and Cluster 1, Cluster 3 and Cluster 5 whose articles were mainly published in recent years are the emerging author's cooperation groups in this field. It can be concluded that the researchers of the subject service research of Chinese university libraries are mainly composed of the seven clusters mentioned above and scholars such as Guo Jing, Ma Fangzhen, Huang Min, and Huang Qinling. Moreover, high-yielding authors are mainly appeared between 2012 and 2018 , which also shows that the research of subject services in university libraries in China has entered a stage of rapid development from 2012. It also further proves that the 
division of the research stages mentioned in the

previous article is correct.

TABLE I. STATISTICS OF THE DISTRIBUTION OF CORE AUTHORS' COOPERATION NETWORK

\begin{tabular}{|c|c|l|}
\hline Clusters(7) & Items(36) & \multicolumn{1}{c|}{ authors } \\
\hline $\boldsymbol{I}$ & $\mathbf{9}$ & $\begin{array}{l}\text { Liu Suqing, Liu Yaqiong, Zhang Chunhong, Zhu Benjun, Li Feng, You Yue, Xiao Long, Ai } \\
\text { Chunyan, Ma Fangzhen }\end{array}$ \\
\hline $\mathbf{2}$ & $\mathbf{6}$ & Lan Xiaoyuan, Song Haiyan, Li Pei, Tang Lihua, Gu Zhaoqian, Gao Xie \\
\hline $\mathbf{3}$ & $\mathbf{6}$ & Fu Jiajia, Zhou Hua, Zhou Zhe, Zhang Xia, Pan Wei, Huang Min \\
\hline $\mathbf{4}$ & $\mathbf{5}$ & Sun Yi, Xu Jing, Zheng Qiaoying, Guo Jing, Chen Jin \\
\hline $\mathbf{5}$ & $\mathbf{5}$ & Yang Mei, Jiang Lili, Chen Youhua, Chen Zhiling, Ma Lihua \\
\hline $\mathbf{6}$ & $\mathbf{3}$ & Liu Zan, Qian Yin, Huang Qinling \\
\hline $\mathbf{7}$ & $\mathbf{2}$ & Yu Xiaowei, Li Li \\
\hline
\end{tabular}

2) Distribution of institutions' cooperation network: The distribution of institutions' cooperation network can reflect the distribution and cooperation of the scientific research institutions engaged in subject service research in Chinese university libraries. By importing the data into the Citespace software, we obtained the distribution map of the institutions' cooperation network and the frequency(partial) of institution cooperation ("Table II"). As shown, there are 484 institutions and 77 connections in the institutions' cooperation network of subject service research in Chinese university libraries, and the overall Density of the network is 0.0007 . Compared with the authors' cooperation network, the institutions cooperation network is more loose, and the main reason for this situation is that most institutions are independent of each other and they cooperate only within the institution. And a total of 410 clusters of different sizes have been formed in the entire institutions' cooperation network, indicating that there is few cooperation between these institutions. There are four institution cooperation groups with strong cohesion have been formed as follows: Shanghai Jiaotong University Library, Guangdong University of Technology, etc. in Cluster 1, Shenyang Normal University Library, etc. in Cluster 2, Xiamen University Library, Tsinghua University Library, Beijing University of Chemical Technology Library, Beijing University of Chemical Technology Institute of
Information Quality, School of Physics of Xiamen University, etc. in Cluster 3, School of Information Management of Wuhan University, Wuhan University Library, etc. in Cluster 4. Among them, Shanghai Jiaotong University Library, Shenyang Normal University Library, Xiamen University Library, School of Information Management of Wuhan University, as the strong force of subject service research of university libraries in China, are at the core of each cluster. According to "Table II", Shanghai Jiaotong University Library is the only institution with a frequency of more than 30 times and only other three institutions have a frequency of more than 20 times. That is to say there are not many core institutions engaged in this field in China among which Shanghai Jiaotong University Library is the core force. From "Table II", it can be known that the main research institutions of the subject service research of university libraries in China are composed of the above four clusters, as well as Heilongjiang University of Chinese Medicine Library, Library of Nantong University, Huzhou University Library, etc. The cooperation between these institutions is relatively loose, which may cause the decline of research results in this field in the future. Therefore, scholars and research institutions engaged in this field should pay more attention to this trend, seize opportunities and strengthen cooperation to promote further research in this field.

TABLE II. FREQUENCY OF INSTITUTIONS' COOPERATION (PARTIAL)

\begin{tabular}{|c|l|l|l|l|l|l|l|}
\hline No. & Frequency & \multicolumn{1}{|c|}{ Institution } & $\begin{array}{c}\text { Year of First } \\
\text { Appearance }\end{array}$ & No. & Frequency & $\begin{array}{c}\text { Fear of } \\
\text { First } \\
\text { Appearance }\end{array}$ \\
\hline $\mathbf{1}$ & 38 & $\begin{array}{l}\text { Shanghai Jiaotong } \\
\text { University Library }\end{array}$ & 2010 & 11 & 14 & $\begin{array}{l}\text { Hubei } \\
\text { Economics Library }\end{array}$ \\
\hline $\mathbf{2}$ & 24 & $\begin{array}{l}\text { Shenyang Normal University } \\
\text { Library }\end{array}$ & 2010 & 12 & 14 & Xiamen University Library & 2012 \\
\hline $\mathbf{3}$ & 22 & $\begin{array}{l}\text { Heilongiang University of } \\
\text { Chinese Medicine Library }\end{array}$ & 2013 & 13 & 14 & $\begin{array}{l}\text { Nanjing University of Science } \\
\text { and Technology Library }\end{array}$ & $\begin{array}{l}\text { 2010 } \\
\text { Commerce Library }\end{array}$ \\
\hline $\mathbf{4}$ & 20 & $\begin{array}{l}\text { Library of Nantong } \\
\text { University }\end{array}$ & 2010 & 13 & University \\
\hline
\end{tabular}




\begin{tabular}{|c|c|c|c|c|c|c|c|}
\hline No. & Frequency & Institution & $\begin{array}{l}\text { Year of First } \\
\text { Appearance }\end{array}$ & No. & Frequency & Institution & $\begin{array}{c}\text { Year of } \\
\text { First } \\
\text { Appearance }\end{array}$ \\
\hline 5 & 18 & Huzhou University Library & 2010 & 15 & 13 & $\begin{array}{lll}\text { Inner Mongolia } & \text { Medical } \\
\text { University Library } & \end{array}$ & 2012 \\
\hline 6 & 17 & Fuzhou University Library & 2016 & 16 & 13 & $\begin{array}{l}\text { North China University } \\
\text { of Science and } \\
\text { Technology Library }\end{array}$ & 2011 \\
\hline 7 & 17 & $\begin{array}{l}\text { Renmin University of China } \\
\text { Library }\end{array}$ & 2007 & 17 & 12 & Wuhan University Library & 2010 \\
\hline 8 & 16 & Peking University Library & 2012 & 18 & 12 & $\begin{array}{l}\text { Guizhou Normal University } \\
\text { Library }\end{array}$ & 2009 \\
\hline 9 & 15 & $\begin{array}{l}\text { School of Information } \\
\text { Management of Wuhan }\end{array}$ & 2010 & 19 & 11 & $\begin{array}{l}\text { Hangzhou Normal University } \\
\text { Library }\end{array}$ & 2011 \\
\hline 10 & 14 & $\begin{array}{l}\text { Hunan University of } \\
\text { Technology and } \text { Business } \\
\text { Library }\end{array}$ & 2011 & 20 & 11 & $\begin{array}{l}\text { Zunyi Medical } \\
\text { University Library }\end{array}$ & 2016 \\
\hline
\end{tabular}

\section{Analysis of research hotspots and evolution trend}

Research hotspots reflect one or more topics of common interest to scholars in a certain research field [7], and keywords as an important element of academic papers are the refinement of the research contents and can fully represent the core topics and research scope of the article [8-10]. Keywords co-occurrence analysis is regarded as the concentrated expression of research hotspots in this field, and its results can directly reflect the research hotspots and evolution rules.

In order to explore the research hotspots and evolution rules of subject service research of university libraries in China, Citespace software was used to make the keywords co-occurrence analysis on the literature from 1997 to 2018, then we obtain a Cluster View of the keywords co-occurrence that reveals the research hotspots ,Time Zone View reveals the evolution trends the and keywords co-occurrence frequency table (partial) ("Table III"). There are 172 keywords in the subject service field of university libraries in China and 335 connections, and the overall Density of the network is 0.0228 as shown. That means scholars in the field of subject service focus on a relatively small number of topics which are almost the same.

TABLE III. KEYWORDS CO-OCCURRENCE FREQUENCY TABLE (PARTIAL)

\begin{tabular}{|c|c|c|c|c|c|c|c|c|c|}
\hline Keyword & Frequency & Year & Centrality & Sigma & Keyword & Frequency & Year & Centrality & Sigma \\
\hline $\begin{array}{c}\text { university } \\
\text { library }\end{array}$ & 992 & 2004 & 0.59 & 1 & "Internet +" & 15 & 2016 & 0.02 & 1 \\
\hline subject service & 863 & 2007 & 0.51 & 1 & $\begin{array}{l}\text { "Double Tops" } \\
\text { construction }\end{array}$ & 15 & 2017 & 0.01 & 1.1 \\
\hline $\begin{array}{c}\text { subject } \\
\text { librarian }\end{array}$ & 418 & 2006 & 0.31 & 11.8 & "Double Tops" & 14 & 2017 & 0.00 & 1 \\
\hline library & 165 & 2009 & 0.20 & 1 & user requirements & 13 & 2012 & 0.02 & 1 \\
\hline $\begin{array}{c}\text { subject liaison } \\
\text { service }\end{array}$ & 90 & 2009 & 0.26 & 4.61 & academic library & 13 & 2012 & 0.01 & 1 \\
\hline $\begin{array}{c}\text { embedded } \\
\text { subject service }\end{array}$ & 83 & 2010 & 0.09 & 1 & $\begin{array}{l}\text { resource } \\
\text { construction }\end{array}$ & 12 & 2012 & 0.01 & 1 \\
\hline $\begin{array}{c}\text { embedded } \\
\text { service }\end{array}$ & 60 & 2012 & 0.14 & 2.22 & $\begin{array}{l}\text { Ubiquitous } \\
\text { knowledge } \\
\text { environment }\end{array}$ & 12 & 2011 & 0.02 & 1 \\
\hline service pattern & 54 & 2010 & 0.19 & 1 & $\begin{array}{l}\text { embedded } \\
\text { librarian }\end{array}$ & 12 & 2012 & 0.01 & 1 \\
\hline $\begin{array}{c}\text { information } \\
\text { service }\end{array}$ & 41 & 2010 & 0.13 & 1 & $\begin{array}{l}\text { Information } \\
\text { Commons }\end{array}$ & 12 & 2010 & 0.01 & 1 \\
\hline $\begin{array}{c}\text { knowledge } \\
\text { service }\end{array}$ & 38 & 2011 & 0.13 & 1 & $\begin{array}{l}\text { subject service } \\
\text { team }\end{array}$ & 11 & 2013 & 0.01 & 1 \\
\hline $\begin{array}{l}\text { subject service } \\
\text { platform }\end{array}$ & 35 & 2012 & 0.08 & 1 & Internet + & 11 & 2016 & 0.02 & 1 \\
\hline $\begin{array}{c}\text { service } \\
\text { innovation }\end{array}$ & 34 & 2012 & 0.06 & 1 & Innovative service & 10 & 2016 & 0.01 & 1 \\
\hline $\begin{array}{c}\text { subject } \\
\text { librarian } \\
\text { system }\end{array}$ & 29 & 2008 & 0.06 & 1.33 & service system & 10 & 2010 & 0.04 & 1 \\
\hline
\end{tabular}




\begin{tabular}{|c|c|c|c|c|c|c|c|c|c|}
\hline Keyword & Frequency & Year & Centrality & Sigma & Keyword & Frequency & Year & Centrality & Sigma \\
\hline university & 26 & 2013 & 0.11 & 1.4 & $\begin{array}{l}\text { document } \\
\text { resource } \\
\text { construction }\end{array}$ & 9 & 2007 & 0.02 & 1 \\
\hline big data & 25 & 2014 & 0.06 & 1.35 & $\begin{array}{ll}\text { subject } & \text { service } \\
\text { pattern } & \\
\end{array}$ & 9 & 2012 & 0.03 & 1 \\
\hline embedded & 22 & 2012 & 0.05 & 1 & $\begin{array}{l}\text { knowledge } \\
\text { management }\end{array}$ & 9 & 2011 & 0.00 & 1 \\
\hline $\begin{array}{c}\text { subject } \\
\text { construction }\end{array}$ & 22 & 2010 & 0.06 & 1 & strategy & 9 & 2012 & 0.01 & 1 \\
\hline Double Tops & 22 & 2017 & 0.00 & 1 & $\begin{array}{l}\text { Analysis of the } \\
\text { survey }\end{array}$ & 8 & 2012 & 0.00 & 1 \\
\hline library service & 21 & 2011 & 0.08 & 1 & $\begin{array}{ll}\begin{array}{l}\text { WeChat } \\
\text { platform }\end{array} & \text { public } \\
\end{array}$ & 8 & 2016 & 0.01 & 1 \\
\hline innovation & 18 & 2011 & 0.05 & 1 & $\begin{array}{l}\text { Library } \\
\text { association }\end{array}$ & 8 & 2013 & 0.00 & 1 \\
\hline libguide & 18 & 2012 & 0.04 & 1 & $\begin{array}{l}\text { sci-tech document } \\
\text { retrieval }\end{array}$ & 8 & 2012 & 0.00 & 1 \\
\hline $\begin{array}{c}\text { local } \\
\text { university }\end{array}$ & 16 & 2010 & 0.03 & 1 & $\begin{array}{l}\text { library } \\
\text { management }\end{array}$ & 8 & 2006 & 0.02 & 1.07 \\
\hline service & 15 & 2014 & 0.07 & 1 & Web2.0 & 8 & 2009 & 0.01 & 1.06 \\
\hline
\end{tabular}

There are 15 clusters in the Cluster View among which the keyword "university library" with the largest area in the central position appears most frequently. That means "university Library" is the central word for research in this field, and this is related to the research area of this article to some extent. Other keywords with larger clusters include "subject service", "subject librarian", "library", "subject liaison service", "embedded subject service", "embedded service", " service pattern", " information service" , est. and so on. These are also hot keywords with a high co-occurrence frequency which is consistent with the statistical results of keywords frequency in "Table III", and they are connected with the core keyword "university library" with the highest co-occurrence frequency through thicker lines, which indicates that these keywords have a strong co-occurrence strength with the central keyword "university Library". According to "Centrality" in "Table III", it is known that the important keywords in the field of subject service research of university libraries in China are as follows: "university libraries" (0.59), "subject service" ((0.51), "subject librarian" (0.31), "subject liaison service"(0.26), "library "(0.20), "service pattern" (0.19), "embedded service" (0.14), "information service" (0.13), "knowledge service" (0.13), etc., which indicates that the research hotspots of subject service in university libraries in China are mainly focused on service pattern, service innovation, embedded service, systems and platform management of subject librarian, subject construction, knowledge services, and the application of emerging technologies and concepts, such as "Internet +", "Big Data", "Double Tops", and The research object is mainly concentrated in the libraries of universities or schools. The purpose of the research is to explore the content and scope of subject service, propose solutions to the existing problems, and predict future development.

We can observe clearly and directly the evolutionary development of research in this field from the Time Zone View. The Time Zone Map provided by Citespace concentrates the keywords nodes that appear simultaneously, that is the time when the keyword first appeared in the literature or was retrieved, in the same time zone, and arranges the sequences in order from far to near in the horizontal axis direction, showing the evolution of research in this field in the time dimension by a visual form, and the lines between keywords nodes in each time zone indicates the inheritance relationship of the research [7] [8]. The development of subject services in Chinese university libraries begins with subject librarians, and has experienced the process from discussing subject librarians, related systems, platforms, subject construction, service content, and service patterns to implementing embedded service, precision service, think tank service, subject evaluation, and improving service capabilities. And this process can be roughly divided into three stages - the first stage is the elementary period (1997-2006) in which although there is some research, it is mainly discussed in terms of concept and preliminary practice and not deep in the content of the service. This may be affected by factors such as low technology at the time, unclear service content and scope, and imperfect subject librarian system, etc.; the second stage is the slow development period (2007-2011) in which information service, service patterns and embedded service begin to be discussed. At this stage, the concept and content and scope of services have gradually become clearer, and the technology has been further improved. However, due to other constraints such as the low speed of network and lack of resources, although subject 
services have developed to some extent, in practice there are still some problems that have caused some development bottlenecks; the third stage is a period of rapid development (2012-2018) in which some keywords with strong practical significance appear, such as "embedded service", "precision service", "think tank service", "Double Tops", "ESI", "subject evaluation" and "Internet $+"$ etc. At this stage, the subject service has deeper exploration content and richer practical content, and some new technologies such as big data and cloud computing have begun to be further practiced and applied in the subject service, which has further improved the subject service capabilities of university libraries, thus, subject services have entered a period of rapid development. It also proves that the division of the research stages mentioned in the previous article is correct.

\section{Conclusion}

This paper uses bibliometrics and knowledge map analysis, such as statistical analysis, co-occurrence analysis and cluster analysis, to analyzes the literature on subject service field of university libraries in China retrieved from the CNKI database and scientifically sorts out the literature growth trend, research power distribution, research hotspots, and evolutionary development, then draws the following conclusions:

First, from the annual distribution and growth trend of the literature, it can be seen that the subject service of Chinese university libraries is in full compliance with the Price Index's document growth law and is in a period of rapid development.

Second, from the distribution of research power, it can be seen that the connection of authors and institutions engaged in research on subject services in university libraries in China is relatively loose, the number of core authors and institutions most of whom are independent is not large, and this may cause the decline of research results in the future .

Third, from the analysis of co-occurrence of keywords, it can be seen that the research hotspots of subject service in Chinese university libraries are mainly focused on service patterns, innovative service, embedded service, subject librarian system, and the application of platform management, subject construction, knowledge service, new technology and new concepts such as "Internet +", "Big Data", "Double Tops"), etc.. The research objects are mainly libraries of universities or schools, and the ultimate purpose is to explore the content and scope of subject service, propose solutions to the existing problems, and predict future development.

Fourth, from the literature growth trend and time zone evolutionary development, it can be seen that the development of subject service of university libraries in
China can be divided into three stages: the elementary period, the slow development period and the rapid development period.

\section{References}

[1] Li Zhifang, A Comparative Analysis on Subject Services Between Domestic University Libraries and Foreign University Libraries - Based on an Investigation of $i$ Schools and'985'University Libraries. Library and Information Service. 2017(6):71-79.

[2] Shi Xiaoqing. The Research of the Discipline Service Model of Local Academic Library Based on the Regional Library Alliance. Library. 2012(5):91-93.

[3] Jiang Airong. Construction of "Subject Librarian" System in Tsinghua University Library. Library Journal. 1999(6):30-31.

[4] Shi Yan, Luo Guiling, Chen Huizi, Zhou Qian, Niu Yanyan. Preliminary Investigation of Embedded Subject Service of University Library to the Chemistry Research. Shandong Chemical Industry. 2018,47(19):126-127.

[5] Chen Jing. Establishing a Professional Team of "Subject Librarian"(Abstract). Jiangxi Library Journal. 1987(10):58-59.

[6] Luo Shisheng. Discussion on the Parameter b of the Price Curve Equation. Information Studies:Theory \& Application. 1994(1):13-14.

[7] Li Jie, Chen Chaomei. CiteSpace: Technology Text Mining and Visualization(2nd edition). 2017.

[8] Lu Xinyuan, Zhang Heng, Wang Xinyue, Qin Zejia. The Analysis of Research Hotspots and Frontiers on Enterprises Knowledge Transfer in Domestic Based on Scientometrics. Information Science. 2019(3):169-175.

[9] Zhao Limei, Zhang Hua. Research Frontier of Chinese Digital Library in Big Data Context - In Perspective of Co-word Analysis. Information Science. 2019(3):97-104

[10] Chu Jiewang, Wang Min. The Hotspots and Trends of Information Service Research in Mobile Libraries in China. Journal of Modern Information. 2019(3):15-23. 